\title{
TRANSFORMATIVE POETRY. A GENERAL INTRODUCTION AND A CASE STUDY OF PSALM 2
}

\author{
ARCHIBALD L. H. M. VAN WIERINGEN"
}

Tilburg University

\begin{abstract}
The structure of Psalm 2 is based on direct speeches in the text. These direct speeches characterise the communication that takes place in the text. The text-immanent author addresses the text-immanent reader with a question in the first line and with a makarismos in the last line. The direct speeches of the characters enable the text-immanent reader to undergo a development in his striving towards the beatitude. In this development, the 'now' of the birth of the Anointed One / Son is re-enacted in the reading moment of the text-immanent reader. The reception of Psalm 2 makes clear that Hebrews and the Christmas liturgy re-use the text, while retaining this re-enactment character.
\end{abstract}

KEY WORDS: Psalm 2, synchrony, Epistle to the Hebrews, introit midnight Mass Christmas, direct speech

\section{Introductory Remarks: the Characteristics of Transformative Poetry}

Transformations occur in every religion, most strikingly in religious initiation. This is also the case for Judaism and Christianity.

In Judaism, the initiatory transformation is marked by circumcision. The ritual includes the new believer in the promises that God made to Abraham. Through circumcision, Abraham experienced in his body the difficult realisation of the promise of a son, and circumcision thus became the expression of his trust, his faith, in the Lord. Circumcision is therefore a sign of faith, both for Abraham and also for the generations to come as in Genesis 17:9-14 (Jacob 1934: 431-434).

When the people of God, set free from slavery in Egypt, entered the land of God's promises, they could only do this as a people who gave expression to their faith. They had not yet done this sufficiently during the journey. The men who were born in the desert were not yet circumcised. As soon as they reached the new land, the initiatory rite of circumcision was performed. The

* $\quad$ ARCHIBALD L. H. M. VAN WIERINGEN (PhD 1993, Radbout University, Nijmegen) is associate professor of Old Testament at Tilburg University. Email: a.l.h.m.vanwieringen@tilburguniversity.edu. 
account which Joshua 5:2-9 gives of this, almost automatically becomes a Paschal narrative in verses 10-12: there is no more manna; it is replaced by the first harvest of the people's own land.

Jewish boys are still circumcised to this day. Circumcision takes place on the eighth day. Their initiation gives them a name within the community of the faithful. The name of the new-born is announced once the bleeding of the circumcision has stopped. This practice appears already in biblical stories. Jesus too received his significant name of 'the Lord Saves' only at his circumcision on the eighth day (Luke 2:21).

Christianity also has a specific rite of initiation. No one is a Christian from birth, people become Christians. This is why they are baptised. Baptism is the fundamental transformation of Christianity. It marks the transition into faith in the Risen Lord Jesus Christ (van Wieringen, Rikhof 2012: 11-47).

It is for this reason that this transition, this transformation in Christ, is emphasised so strongly. Before baptism there is a process during which the person to be baptised is a catechumen, and is initiated into the mysteries of faith through baptismal catechesis. Baptism itself normally takes place during the Easter vigil. The assembled congregation holds vigil during the night of the resurrection so that it may celebrate the sacraments at first light. The catechumen is baptised and is then invited, for the first time, to partake of the Table of Bread and Wine. During the octave of Easter, the neophyte receives further instruction, which is traditionally called mystagogical catechesis. ${ }^{1}$

The transformation undergone by the person who is baptised is made visible in several ways. Thus in the ritual of baptism during the Easter vigil, the person to be baptised literally leaves his old clothes behind, and is clothed in white clothes after being submerged in the baptismal font (Ephesians 4:24; Colossians 3:9-10). He/she is reborn as a new, naked Adam: he/she has died to the old life, and the new life happens to him/her under the aspect of brilliant whiteness. The neophyte becomes like the Risen Lord himself.

Baptism is a one-off event. It is a unique moment of transformation in Christianity. ${ }^{2}$ But it does not complete the process of transformation. The believer sets out on a path of transformation that lasts the rest of his/her life.

The Judeo-Christian tradition's many mystical texts point to the importance of the ongoing transformation that each believer must experience permanently in his/her way towards God. Transformation is thus an essential

1 The transformative process of baptism presupposes adult baptism. The Second Vatican Council therefore regards adult baptism as the norm, while infant baptism is seen as derived from it

2 There is no such thing as rebaptising. Mutual recognition of baptism in the context of Christian ecumenism is therefore a good thing.

PERICHORESIS 14.2 (2016) 
characteristic of spiritual development, which is not limited to the moment of official initiation alone.

Poetry is a genre in which this enduring and ongoing transformation can be expressed very clearly. It can articulate the relationship with God in an open way that is often multi-interpretable. Whereas theological teaching requires the genre of a treatise, with sharp definitions and univocal meaning, the poetic form, with all its literary tensions, is suitable to express the tension and ambiguity of the relationship with God.

The step towards literary representation does, however, add a new relationship to the ongoing process of transformation: the reader of the text is now also involved in this process by the author. The text, the poem in particular, is not so much a reflection of the historical author's feelings and experiences (if he can even be identified), but expresses the transformations of the actants who are present in the poem, as well as the transformations of the reader. The author of the text initiates his reader into the process of transformation that his poem describes—or rather: that his poem itself is.

This kind of poetry can best be described as 'transformative poetry' (Laude 2005: 209). The transformative character is performed at various levels in these poems.

The poet, as producer of the text, poetically describes the religious change that he has undergone. In this way, the poem can itself be part of the process of conversion that the author is experiencing, as was the case for instance in Wystan Hugh Auden's Musée des Beaux Arts, discussed elsewhere in this edition of Perichoresis, or the poem can be the expression of an all-encompassing mystical experience in the depth of the human soul, as Francis' Canticle of the Sun and Thomas Aquinas' Adoro Te Devote demonstrate discussed elsewhere in this edition of Perichoresis as well.

However, transformations can also happen to the characters that appear in the text itself. Psalm 2, which is the subject of this article, deals with kings who rebel against the Lord's Anointed, kings who are also, in a hidden way, given what might be called 'a second chance'.

In addition to the poet himself and the characters within the poem, transformative poetry explicitly focuses on the reader. The reader of a poem is not a passive consumer, but is involved in the process of transformation as an active partner. He or she can be addressed very explicitly, as is the case-in this edition of Perichoresis-with the Donatist Christians whom Augustine hoped his Psalm against the Donatists would induce to return to the Catholic Church, or with the recently converted Saxons who had to be brought closer to Jesus and the Gospel through the Heliand. But the reader can also appear as a textual entity, concealed within the text. This happens in Psalm 2 because the reader is made to witness the communications concerning the Anointed 
which take place in the text, and is moreover implicated in these communications.

The transformative character of poems is also evident in the way in which they affect their readers. In their reception by readers, transformative poems have remarkably often and remarkably quickly become generally appreciated hymns. The Canticle of the Sun became a sermon hymn for the Franciscan Friars, and the Adoro Te Devote, originally a poem of personal devotion for use during the celebration of the Eucharist, turned into a public Eucharistic hymn.

Intertextual influence can already be discerned in Scripture itself. Thus Psalm 2 is taken up again and quoted in the Epistle to the Hebrews, to describe Jesus Christ's most fundamental transformation, his resurrection.

Finally, it can be noticed that transformative poetry often contains various, more or less direct, allusions to the Bible. These allusions are to both biblical forms and biblical texts. In this issue of Perichoresis, an example regarding biblical forms is Augustine's Psalm against the Donatists, which as an abecedary is grafted onto the alphabet poem Psalm 119. An example about biblical texts can be found in Aquinas' allusion to Luke 23:39-43 in his Adoro Te Devote.

\section{The Poem Psalm 2}

Poetry always involves a surprising tension, and this is certainly the case for transformative poetry. In this contribution I will propose a reading of Psalm 2. We will read the text in a poetic layout:

\begin{tabular}{|c|c|c|c|c|c|c|}
\hline & cola & & & stresses & strophe & stanza \\
\hline 1 & $\begin{array}{l}\text { למה רגשו גוים } \\
\text { Why did the } \\
\text { nations rage }\end{array}$ & $\begin{array}{l}\text { ולאמים יהגו־ריק } \\
\text { and the peo- } \\
\text { ples mutter fu- } \\
\text { tilely? }\end{array}$ & & $3+2$ & I & I \\
\hline 2 & $\begin{array}{l}\text { יתיצבי מלכי־אריץ } \\
\text { The kings of } \\
\text { the earth } \\
\text { take up } \\
\text { position, }\end{array}$ & $\begin{array}{l}\text { ורוזנים נוסדויחיח } \\
\text { after the digni- } \\
\text { taries have sat } \\
\text { down to } \\
\text { gether, }\end{array}$ & $\begin{array}{l}\text { ועל-משיחיחי עליחו } \\
\text { before the } \\
\text { LORD and } \\
\text { before his } \\
\text { anointed. }\end{array}$ & $2+2+2$ & II & II \\
\hline 3 & $\begin{array}{l}\text { את־מוסרותימו: } \\
\text { 'Let us break } \\
\text { their fetters }\end{array}$ & $\begin{array}{l}\text {-ליכה ממנו עבתימוּ } \\
\text { and let us take } \\
\text { off their ropes } \\
\text { from us.' }\end{array}$ & & $2+3$ & III & \\
\hline 4 & $\begin{array}{l}\text { יושב בשמים ישחים } \\
\text { He who sits } \\
\text { in heaven } \\
\text { laughs. }\end{array}$ & $\begin{array}{l}\text { ארני ילענ-למור } \\
\text { the Lord } \\
\text { mocks them. }\end{array}$ & & $3+2$ & IV & III \\
\hline 5 & ידבר אלימו באפוּ & $\begin{array}{l}\text { ובחרונו יבהלמוּ } \\
\text { and in his }\end{array}$ & & $3+2$ & & \\
\hline
\end{tabular}


Then he rage he disin-

speaks to herits ${ }^{3}$ them:

them in his

anger

6 ואני נסכתי מלכי

'But I myself

have poured

על־ציון הר־קדשי

on my holy

$2+2 \quad \mathrm{~V}$

out [oil] over

mount Zion.'

my king

$7 \quad$ אל חק יהוה

אספרה

אמר אלי

he has said to

$3+2 \quad$ VI

III

'Let me

me:

announce

concerning ${ }^{4}$

the decree

of the LORD,

בני אתה

«You are

אני היום ילדתיך

$2+3 \quad$ VII

my son,

hereby I give

birth $^{5}$ to you

today.

8 שאל ממני 8

Ask of me

ואתנה גוים נחלתך

and I will give

nations as your

inheritance

$\begin{array}{ll}\text { ואפסי-ארץ } & 2+3+3 \\ \text { and as } & \\ \text { your pos- } & \\ \text { session } & \\ \text { until the } & \\ \text { ends of } & \\ \text { the earth. } & \\ & 3+3\end{array}$

9 בשבט ברזל 2 May you

בכלי יוצר תנפצם

$3+3$

break them

shatter them

with an iron

as an earthen

rod,

מלכים השכילו 10

ועתה

jar.»'

'And now,

הוסרי שפטי ארץ

be warned,

$3+3$

kings, be

judges of the

wise,

את־יהוה ביראה 11

עבדו world.

Serve the

וגילו ברערה

and shout for

$3+2$

LORD with

joy with

awe

trepidation.

Lam 2014: 38-43.

The verb 2 'to tell' is usually constructed with a direct object. In order to do justice to the special construction, I have translated the preposition אל מא as ancerning'.

5 The Hebrew verb ילד means 'to give birth'; regarding the birth imagery, both the masculine 'to beget' and the feminine 'to give birth' can be used here (Curtis 2007: 55). 


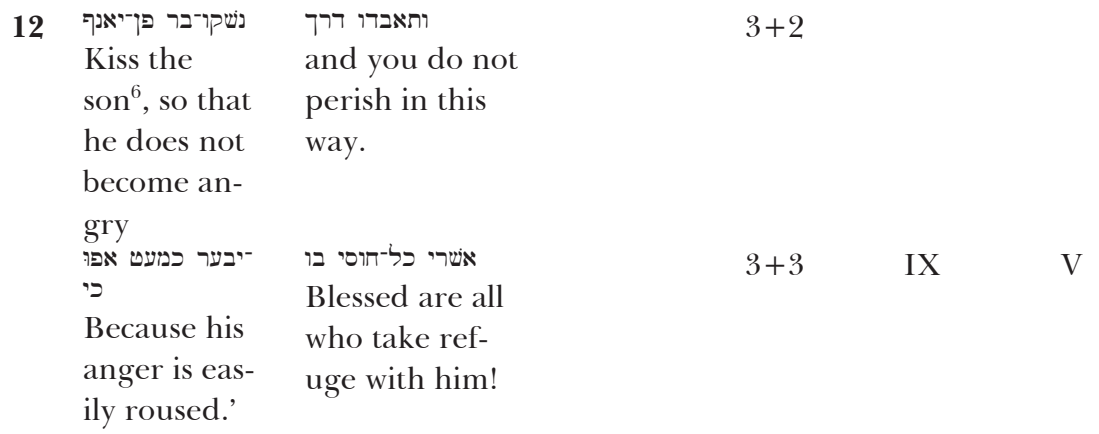

A detailed analysis of all aspects of the Hebrew poetic structure of this poem would take us well beyond the scope of the current contribution (van Grol 2015). Instead let me point out a number of basic aspects. Thus in Hebrew verse, lines consist of two or three cola that are held together by parallelism. The parallelism is both syntactic and semantic. Thus there is parallelism in verse 1 between the words 'nations' and 'peoples' and the verbs 'rage' and 'mutter'. The verbal forms have the same verbal tense (qatal forms, which must be translated into English in the simple past because of their retrospective character). In addition, 'nations' or 'peoples' are the subject of the verb in both cola. The interrogative 'why' at the start of the first colon also determines the second colon, so that the entire line is an interrogative sentence. The higher levels are also characterised by syntactic and semantic parallelism, but I will not examine these further in this contribution. Furthermore, important in this poem are the macro-syntactic signals is 'then' (verse 5) and יעתה 'and now' (verse 10), which also mark the beginning of higher poetic units.

\section{Synchrony and Diachrony}

Our attention is focused on what happens in this poem. Characters appear in the poem who relate to each other; these relationships develop during the poem. The reader, however, who is present in the text is also involved in these changes. What are the developments that this text-immanent reader undergoes?

These questions are different from the questions asked by diachronic exegesis, which seeks to establish a historical context for the text. Psalm 2 is traditionally seen as a song for the enthronement of a new king in Jerusalem, or for the annual commemoration of this event; this view derives from the work of Herman Gunkel and Sigmund Mowinckel (Otto 2004). There are certainly textual signals that support this vision. The word 'king' (verse 6) is,

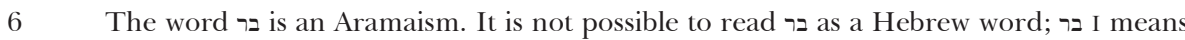
'grain' and does not fit in the poem semantically, while בר II 'pure' only occurs as a predicate (Clines 1995: 207).

PERICHORESIS 14.2 (2016) 
of course, the most important one. The fact that the enemy 'kings' who ultimately seem powerless must take up position before the anointed king and he who has performed the anointing, evokes the image of the enthronement of a king. This act is rare in the Bible, and it is associated mainly with God's heavenly court in Job 1:6; 2:1. There will certainly have been enthronement ceremonies in ancient Israel; but the Bible does not mention them much. The most important example is that of king Jehoash in 2 Kings 11, but he became ruler of the Northern Kingdom, not in Jerusalem.

Some exegetes have regarded Psalm 2 as a song for the annual celebration of the kingship of the Lord God. God is in fact portrayed as a king in the Bible. In the book Isaiah, the word 'king' is used almost exclusively for God (see for instance 6:1), but God is not designated as 'king' anywhere in this particular Psalm. The image of God enthroned in the heavens is not in itself mistaken, but verse 4 has the common Hebrew verb 'to sit'; translating this as 'to be enthroned' is to prematurely privilege one specific interpretation. In addition, we have no information that any such hypothetic feast actually existed (Kraus 1992: 115-116).

\section{Direct Speech in the Poem}

A first step to understanding what is happening in this poem is to identify the direct speeches. Direct speech is characterised by the presence of a first and / or second person. The first person is the speaker of the direct speech, the second person is the addressee. The addressee can be made explicit by using a vocative.

The verbal tense used sometimes also indicates whether there is direct speech or not. The modal yiqtol, the subjunctive mood in English, normally indicates that there is direct speech. In narrative texts, the transition to nonnarrative verbal forms also points to direct speech. Nevertheless, because Psalm 2 is not a narrative text, it has no such transitions.

Furthermore, direct speech is often introduced with a formula containing a verbum dicendi. In Hebrew, the verbum dicendi must at least contain the verb אמר 'to say'; if there is another verbum dicendi, the word לאמר is usually added, which is best translated in English by a colon. Direct speech can theoretically be concluded with a formula, but this is extremely rare in the Old Testament.

Verse 3 is characterised in both cola by the first person plural. The verbal tense is a modal yiqtol. Because neither verse 2 nor verse 4 have the first person plural, the direct speech here is limited to verse 3. Although the direct speech in verse 3 is not introduced, the identification of the first person plural poses no problems: the 'kings' of verse 2 appear as speakers in verse 3 . Because there is no second person, we can conclude that the direct speech is not 
intended to address any third party, but for internal communication within the 'we'-group. ${ }^{7}$

Verse 6 begins with an emphatic first person singular, expressed in the separate personal pronoun ואני 'but I'. The presence of this first person also marks the start of direct speech. Verse 5 shows that this direct speech must be seen as a reaction to 'them', which refers to the 'kings' in verse 2 . It remains to be seen, however, whether verse 5 also functions as an introductory formula to the direct speech in verse 6 . It is true that there is a verbum dicendi, דבר 'to speak', but there is no form of the required verb אמר 'to say'. ${ }^{8}$ This means that it is doubtful whether the direct speech in verse 6 represents what the Lord says to the kings in fetters. They are no longer important, and neither, by consequence, is communication with them. Verse 6 contains communication of the Lord with himself, 'after' he has addressed and astonished the kings. This explains why the direct speech in verse 6 begins with the conjunction ! 'but'; it refers back to what the Lord said before, but was not included in the poem because it was unimportant. In this way the parallelism between verse 3 and 6 becomes very strong: both verses contain internal communication, within the group, or with the speaker himself, not communication that addresses someone else.

The direct speech that begins in verse $6 \mathrm{a}$ ends in verse $6 \mathrm{~b}$, but this does not become clear until verse $7 \mathrm{a}$. Because verse $7 \mathrm{a}$ also contains a first person singular in the verbal form אספרה 'let me announce', it only becomes evident at the last word of verse 7a, יהוה 'the LORD', that verse 7a is not a continuation of the direct speech in verse 6 . The renominalisation of the Lord shows that a different ' $I$ ' is speaking.

Verse $7 \mathrm{~b}$ introduces direct speech, recognisable by the verbum dicendi 'to say', and it is direct speech embedded within the direct speech of the 'I' who began this direct speech in verse $7 \mathrm{a}$. This embedded direct speech is marked in verse 7c with the separate personal pronoun אתה 'you'. This second person singular, the addressee of the direct speech, continues to be present up to and including verse $9 \mathrm{~b}$ and is visible in every colon, either in the form of the verb or in the suffixes used.

The embedded direct speech in the verses $7 \mathrm{c}-9 \mathrm{~b}$ is therefore spoken by the Lord and contains the content of his decree. It is addressed to the 'I' who is the speaker of the preceding verses 7a-b, and who is portrayed as 'son' of the speaker of the embedded direct speech. this reading overlooks the absence of a second person.

8 See also Rashi's Psalm commentary, which interpolates a form of אמר 'to say' to turn verse 6 into a direct speech immediately following verse 5 (Gruber 2004: 177-181).

PERICHORESIS 14.2 (2016) 
The verses 10a-b are immediately identifiable as direct speech because of the presence of the vocatives שלכים 'kings' and שרטי ארץ 'judges of the world'. The question is whether verse 10a is the continuation of the direct speech in verses 7a-b. At first sight this appears to be the case, but because 'son' functions as object of the imperative in verse $12 \mathrm{a}$, and is therefore present in the text as third person, it is unlikely that verse 10a and the following verses are spoken by the same character as the verses $7 \mathrm{a}-9 \mathrm{~b}$. Had that been the case, it would have read: 'kiss me, so that I do not...'

This means that the verses 7-9 contain a direct speech, without being marked by an introductory formula. It is also clear that a new direct speech commences in verse $10 \mathrm{a}$, which is not introduced by a formula either.

There is no indication of who the speaker of the direct speech in verses 10-12c is. Because the Lord and the son both appear as third persons in this direct speech, they must be ruled out as speakers.

Verse $12 \mathrm{~d}$ also requires some attention. I do not regard this verse as part of the direct speech in verses 10-12c (Fokkelman 2000: 56). As a makarismos, verse $12 \mathrm{~d}$ is a general statement, not directed at any one addressed as 'blessed are you', but at כל 'all'. Furthermore, from a semantic perspective, it must be observed that the activity of non 'taking refuge' does not appear in a direct speech in verses $10-12 \mathrm{c}$.

However, a makarismos presupposes a speaker. In this context of a general makarismos, which is distinct from the immediately preceding direct speech, the text-immanent author must be presupposed to be the sender.

A related question is the antecedent of the third person singular suffix in the modifier בו 'with him'. The nearest third person singular is בר 'son' in verse 12a; but it might also be הוה 'the LORD' in verse 11a. But because I think verse $12 \mathrm{~d}$ does not belong to the direct speech in verses 10-12c, the suffix's antecedent must be the nearest third person singular not included in any direct speech. That is אדני 'the Lord' in verse 4b. Possibly it refers to יהוה 'the LORD' in verse 2c, including משיחו 'his anointed'.

Finally, we come to verse 1, which is an interrogative sentence, marked by the interrogative word למה 'why'. A question generally presupposes an addressee; it is assumed that someone will be able to answer. However, because there is no first or second person in this interrogative sentence, it is most likely that the text-immanent author should be seen as the sender of the question rather than one of the other characters. This means that it is the textimmanent reader who is expected to answer the question. I will return to this later. This argument about direct speech in Psalm 2 can be represented schematically as follows:

$\begin{array}{lll}\text { Ia } & \text { verse } 1 & \text { text-immanent author: question } \\ \text { IIa } & \text { verse } 2 & \text { concerning the kings }\end{array}$




\begin{tabular}{|c|c|c|}
\hline $\mathrm{IIb}$ & $\begin{array}{l}\text { verse } 3 \\
\text { verses } 4-5 \\
\text { verse } 6\end{array}$ & $\begin{array}{l}\text { DS of the kings = internal communication } \\
\text { concerning the Lord } \\
\text { DS of the Lord = internal communication }\end{array}$ \\
\hline IIIa & $\begin{array}{l}\text { verses } 7-9 \\
\text { verses } 7 c-9\end{array}$ & $\begin{array}{l}\text { DS of the } \mathrm{I}=\text { the son } \\
\qquad \text { embedded DS of the Lord = decree }\end{array}$ \\
\hline IIIb & verses $10-12 \mathrm{c}$ & DS of unknown speaker \\
\hline $\mathrm{Ib}$ & verses $12 \mathrm{~d}$ & text-immanent author: makarismos \\
\hline
\end{tabular}

The elements Ia and Ib are both direct speech-like elements because of the text-immanent author. They form the poem's inclusio. ${ }^{9}$ Inside, there are two main parts, which in turn consist of two elements. The elements IIa and IIb contain parallelism. Both first describe something in relation to a character, who then speaks in direct speech. These two direct speeches are not, however, addressed to third persons, but to the speakers themselves. The elements IIIa and IIIb both contain direct speech, but without being marked as such by an introductory formula. In this sense, the elements IIIa and IIIb also contain parallelism. Both direct speeches have a special characteristic: the first contains an embedded direct speech, the second has an unknown speaker.

\section{The Development of Events in the Poem}

This structure clarifies the events that occur within the inclusio of the poem.

We turn first to the II-elements. Kings take up position, as if in a court. Verse $2 b$ indicates that the timeline in the poem has begun even earlier. Dignitaries have already sat down together. ${ }^{10}$ The kings do not appear out of nothing, but a circle of dignitaries has already taken their seats; they form the backdrop against which the presentation can take place (Bovati 1994: 233-235).

Verse 3 represents the kings' thoughts. Because there is no introductory formula, this verse evokes simultaneity with the appearance of the kings, and in fact the kings turn out to be in fetters. Some event has obviously taken place before their appearance, which transformed the kings into fettered kings.

In verses 4-6 the poem shifts to the Lord. This turn was prepared in verse 2c: the kings appear before the Lord and his anointed. The Lord mocks the option expressed by the kings. More importantly, it has angered him and he

$9 \quad$ Many different divisions of Psalm 2 have been proposed (van der Lugt 2006: 103-104). The division that I am proposing, with an inclusio formed by the verses 1 and $12 \mathrm{~d}$ is new in certain respects, because I believe that not enough weight has hitherto been given to the positioning of the various direct speeches (Hunter 2005: 50-51).

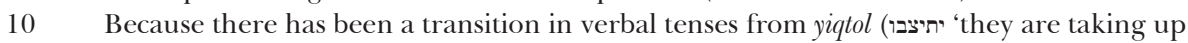
position') to qatal (ניכדי 'after they had sat down together') the רוזנים cannot be the same as the מלכי־אריץ.

PERICHORESIS $14.2(2016)$ 
rebukes them. The kings may desire a thing, which is articulated in direct speech in verse 3 , regarding rebellion, but the Lord has created a situation that makes this impossible, something articulated in direct speech in verse 6 . As the kings' words revealed that they had previously been subject to a transformation, the Lord's words also point to a transformation: they reveal that someone has been made king on the holy mountain of the Lord by having been anointed.

The transformation that the kings had to undergo was a degradation, the transformation wrought by the Lord, on the contrary, is a promotion. The juxtaposing of these contrasting movements places them in relationship with each other. The appointment of the anointed king in the past coincides with the capture of the kings.

The III-elements contain direct speech without introduction. This makes it seem as if they are spoken in the now. Now the son will speak. What the son describes as the decree of the Lord in part IIIa, had already been mentioned in part IIb. While verses 4-5 point-without direct speech, implicitly as it were-to the futility of the rebellion which the kings desire, the 'I' extensively articulates this futility in verses $8-9$. While verse 6 , which contains direct speech, addresses the appointment through anointing with oil according to the designation of משיח 'anointed' in verse 2c, the 'I' in verse 7 calls the relationship between himself and the Lord a relationship of sonship. In this way, the two aspects of the content of the poem are placed in a chiastic relation to each other.

The word היום 'today' (verse 7d) occupies a special position. This moment in time is not the moment of speaking in the text's now, but is the time in the past when the son who speaks in the now was appointed. The words of God, arising from the 'today' moment, to break the nations with an iron rod and to shatter them as earthen jars, represent the future vis-à-vis the 'today' that is represented by the kings in fetters in the 'now' of the text. The 'today' is therefore the past, but its connection to the now, in addition to the absence of any introduction of the basic direct speech in verses 7-9, make it sound as a past that is being constantly re-enacted again in the now.

The IIIb-element again consists of direct speech without introduction, which also therefore takes place in the now. After the words of the appointed anointed king / son who has been born, the kings, i.e. the former judges of the world, are addressed. It seems to me that the speaker of this direct speech are the dignitaries from verse $2 \mathrm{~b}$. They call on the kings to serve to the Lord and kiss the son. ${ }^{11}$ He who does these things has no reason to fear his anger.

Perhaps the Aramaic word בר בר מ hand to distinguish from the 'official' language of the decree in the verses $7 \mathrm{c}-9 \mathrm{~b}$, on the other to use the widespread Aramaic languages to portray the מלכייארי as foreigners and therefore as outsiders. 
And his anger is easily roused. The dignitaries have no reason to fear his anger; they form the backdrop against which the presentation takes place. It seems that their wise counsels suggest that even the fettered kings might undergo a transformation to the place where the dignitaries currently are. The way this is expressed does not refer simply to submission. The word is 'to kiss' in particular points to a different kind of relationship.

The direct speech in verses 10-12c finally addresses the kings directly, which is emphasised by the particle ועתה 'and now'. The Lord has already addressed them in verse $5 \mathrm{a}$, but the content of what he said has been omitted from the text. It is true that the I announces the Lord's decree concerning his appointment and its consequences for the nations, but he does so without addressing anyone in particular. This means that the kings were not the addressees of the direct speech in verses 7-9. They are addressed only at the very end of the poem, with a double message: anger and perhaps a possible transformation.

\section{The Position of the Text-Immanent Reader in the Poem}

We turn now to the text-immanent reader. Where in the text can he be found and what transformation does he undergo ${ }^{12}$

The passage where the text-immanent reader is primarily addressed is the communication by the text-immanent author in the inclusio in verses 1 and $12 \mathrm{~d} .{ }^{13}$ On the basis of qatal forms, verse 1 is focused on the past: why did the nations and the peoples rage? By contrast, verse $12 \mathrm{~d}$, as a makarismos, is future-oriented. This means that there is a development from past to future between verse 1 and verse $12 \mathrm{~d}$. The poem helps the text-immanent reader to realise this development.

The question posed in verse 1 is answered twice. In the II-elements it is answered directly in the words of the Lord in verse 6 , and in the III-elements it is answered indirectly in the words of the Lord in verses 7c-9 as embedded direct speech of the one appointed by the Lord in verses 7-9. This repetition underscores the importance of the answer and makes it possible to use two images of the appointed person: he is an anointed one-the Lord's anointed - and he is a son, the Lord's son.

The text-immanent reader has to do considerably more for the repetition in the III-elements. Neither the beginning nor the end of the direct speeches are initially very clear. The question of the identity of the speaker of the direct speech also demands careful attention on the part of the text-immanent

12 'Readers' come in many shapes and sizes: for methodical discussions (van Wieringen 2012), and for the Psalms (Brown 2010: 161-117).

13 I am limiting myself to Psalm 2 in this contribution. Other connections are also at play in the context of the entire book of Psalms, such as the inclusio between 1:1a and 2:12d (Wallace 2007: 272; Weber 2007: 186-187).

PERICHORESIS 14.2 (2016) 
reader. The embedded direct speech of the Lord, by contrast, poses no problems amid the reading difficulties of the III-elements, neither as regards its beginning and end, nor as regards its speaker. For the text-immanent reader, this positioning of the Lord and his words also highlight the right answer to the question which the text-immanent author posed in verse 1 .

The first three of the poem's four direct speeches are characterised by the absence of an addressee. One reader-oriented technique is to involve the textimmanent reader in the communication in this way. This, however, does not apply to the first direct speech: the kings in verse 3 all speak to each other. The text-immanent reader does not form part of the 'we' of the kings.

This is different for the second direct speech. Although God is not addressing anyone, and there is a parallel communicative setting with verse 3 , the text-immanent reader does hear the Lord's words. These words deal with the past; the past concerning which the text-immanent reader is required to formulate an answer.

The third direct speech is not addressed to anyone in particular either. But this speech does not aim to create self-oriented communication. On the contrary, it is an announcement, which in and of itself assumes the presence of an audience. The text-immanent reader can therefore regard himself as the addressee of the direct speech of the 'I'.

However, this also evokes a particular tension: has he been given to the son as his birth right in an agreeable manner, or may he also become the object of the activity of submission? Both have occurred in the past, so that the text-immanent reader should be able to know where he stands. Nevertheless, the question of the text-immanent author in verse 1 implies that he is (still?) external to the event and is drawn into it by the asking of the question. This is why the 'today', which lies in the past, can move forward to the text-immanent reader's moment in time.

The text-immanent reader is not the addressee of the last direct speech, because the kings are explicitly mentioned as addressees. He does of course hear the content and is therefore also apprised of the option that a possible shift might yet occur from being in fetters, opposing the appointed one, to being part of the backdrop, on the side of the appointed one. The poem concludes with a makarismos. This concerns 'all', including the text-immanent reader. In fact, because of the right answer to the question asked in verse 1 , the text-immanent reader knows what position the one appointed by the Lord occupies, and consequently what his attitude towards the event is. If the text-immanent reader has read the poem correctly and, having begun at the beginning, he can also be said to have arrived at the end, then he may count himself among the blessed who take refuge in the Lord's anointed, respectively in his son. 


\section{Examples of the Reception History of Psalm 2}

Psalm 2 has had a long reception history. I would like to mention two examples.

The first is the reference to verses $7 \mathrm{c}-\mathrm{d}$ in the New Testament, where Hebrews 1:5 uses these as a quotation from the Old Testament: 'For to which of the angels, has [God] ever said: "You are my son, today I have begotten you"?' (Otto 2010: 22-26) This reuse of Psalm 2:7c has three important aspects: 'son', 'to beget' and 'today'.

The writer of the letter to the Hebrews wants to focus on Jesus as son. $\mathrm{He}$ therefore only mentions the proper name Jesus for the first time in Hebrews in 2:9, but he uses the title of 'son' from the start. What is special is his sonship, which makes him greater than the prophets and the angels. In Psalm 2, too, son is a special designation. The word מלך 'king' is used for both the special leader figure in Jerusalem (verse 6a) and for the leaders of the peoples who are in fetters (verses $2 \mathrm{a}$ and 10a). For this reason, the appointed one is presented in the II-elements as someone appointed through anointing with the words משיח 'anointed' and נסך 'pour' and in the III-elements as / בן 'son'. Hebrews has read this succession of 'anointed' and 'son' as a climax; not without reason, because the sonship in Psalm 2 is formulated in an embedded direct speech.

Jesus has received this sonship from God, just as the son in Psalm 2 is

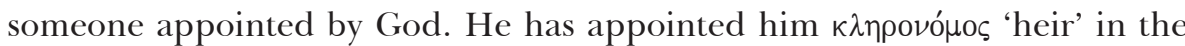

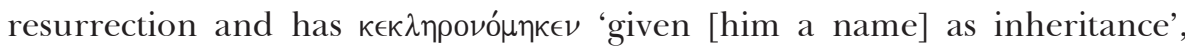
which is higher than all things and all people (Hebrews 1:2-4). This prepares the quotation from the Psalm in verse 5. In Psalm 2:8 the son is characterised by the 'inheritance' that he receives from God, translated in the Greek of the Septuagint as к $\lambda \eta \rho о \nu о \mu i \alpha$. This inheritance essentially consists of everything: nations, even the ends of the earth. The word 'all' does not yet appear in verse 8 , however, but is used, positively, as the end of Psalm 2 in verse 12d: 'blessed are all'. This wide perspective of all things and all people is used in the same positive manner in Hebrews, and it is prepared by the largest conceivable inheritance of Psalm 2:8.

The verb $\gamma \in \nu \nu \alpha \dot{\omega} \omega$ 'to beget' in Hebrews 1:5 reprises the Hebrew verb ילד 'to give birth' in Psalm 2:7d. In both Psalm 2 and the Epistle to the Hebrews, these words are used metaphorically. Psalm 2 focuses on the fact that the king appointed by God in Jerusalem is born for sonship, in Hebrews the birth is interpreted as the resurrection, the new life, which Jesus was given by God in Jerusalem and which also forms the basis for his appointment as son by God.

The word $\sigma \eta \dot{\mu} \mu \rho \circ \nu$ 'today' also plays an important role in the letter to the Hebrews. It is introduced through a quotation from Psalm 2:7c-d. In Psalm 2 , the time indication 'today' primarily refers to the past, which is evoked by 
the 'I' in a way that makes it real again in the present; a re-enactment that, as we have seen, was particularly functional to the text-immanent reader. In Hebrews, 'today' has a comparable position. On the one hand it indicates the past moment of the resurrection of the son, on the other hand it is part of a timeline that runs from $\pi \alpha \dot{\alpha} \lambda \alpha \iota$ 'past' (verse 1), via 'today' from the quotation from the Psalm in verse 5, to a future and as yet unfulfilled moment of return ( $\pi \alpha \dot{\lambda} \lambda \iota v$ 'once again') of the son in verse 6 . This development over time is not unrelated to the text-immanent reader in Hebrews either, as the first person plural in verse 2 clearly indicates: the past is linked to the 'fathers' (in the

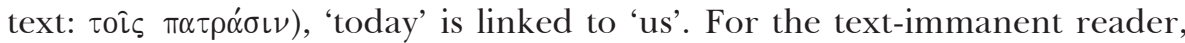
this first person plural is the way through which he has access to this development over time. If it might possibly be the case that these 'fathers' are not his-the possessive pronoun 'our' is remarkably absent from 'fathers'-then he can still feel that he has been addressed by the son of resurrection, so that future salvation is also open to him.

This quotation from Psalm 2:7c-d appears again in Hebrews 5:5. Once again, sonship and begetting are linked to Jesus' resurrection. The repetition of the quotation highlights its importance. Moreover, in Hebrews 5:5 the quotation is used to create a bridge to Jesus' priesthood, in part by linking Melchizedek to a new quotation from Psalm 110:4. ${ }^{14}$ This is possible because Psalm 2 does not mention Jerusalem, but 'my holy mount Zion', which is the Temple Mount. In an associative way, the begetting of the son in Psalm 2:7d is continued in the begetting of Melchizedek, who fulfils a role in Hebrews $7: 3$. Melchizedek has no father or mother, and no pedigree. Because all this is absent, which means he is, as it were, neither preceded nor succeeded by anyone, he is like the son of God as an eternal priest. A parallel is thus established between the origins of Melchizedek and the origins of the son in the quotation from Psalm 2:7c-d (for the idea of divine descent in Psalm 2:7, see Granerød 2010). The concluding verse, Hebrews 7:28, can possibly be seen as an allusion to Psalm 2:7, if the Septuagint's translation of $\pi \rho \circ \sigma \tau \dot{\alpha} \gamma \mu \alpha$ for

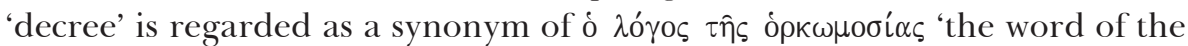
oath'.

The second example of the reception history of Psalm 2 comes from the Roman liturgy's celebration of midnight mass for Christmas. The introit of this mass is derived from Psalm 2. The verses 7b-c make up the antiphon: 'Dominus dixit ad me: Filius meus es tu, ego hodie genui te'. Of course the entire Psalm may be sung for the introit, but it always includes the first verse: 'Quare fremuerunt gentes, et populi meditati sunt inania?'

Because it is Christmas, the feast of the birth of the Lord, this connects Psalm 2 not only to Jesus Christ, but specifically to his birth. The sonship that

14 In early Judaism, the title 'son' in Psalm 2:7 was interpreted as referring to the priestly heir of Levi (Brooke 2004: 17). 
is addressed in Psalm 2 is reprised to explain Jesus' sonship. The birth mentioned in verse $7 \mathrm{~d}$ thus acquires the perspective of the birth of Jesus in Bethlehem.

The antiphon does not start with verse $7 \mathrm{c}$ of Psalm 2, but with verse 7b, and this means that the 'I' is the speaker, and not God. This has a very particular effect: the newly-born is presented as the speaker. Various theological interpretations are possible. Against the background of Christmas, the fullness of the incarnation is asserted: the incarnation is so real, that this human being can in fact be presented as a speaker. This also makes it clear that the focus is not on an infant—an infant cannot speak—but on God's saving acts in this human being. Perhaps it also means that it is not only about the birth two thousand years ago in Bethlehem, but also about the eternal birth from the Father.

The concept of hodie 'today', occupies a comparable position in the liturgy as it does in Psalm 2:7d. The 'today' is in the past, where it concerns the birth of Jesus at the time, but because the liturgy is re-enactment, the users of the text within the liturgy, i.e. the text-immanent readers of the antiphon, are involved in the birth and its effects. On the basis of this verse from the Psalm, a distinction is made between the text-immanent reader and the 'gentes' and 'populi'. The futility of their actions is linked to their failure to recognise the birth of the Lord. Recognising this birth, by contrast, gives the actions of the text-immanent reader their significance.

These two examples of the reception history of Psalm 2 show that the appointment as son, the birth, can be applied to various moments of Jesus' life: to his resurrection in Jerusalem and his birth in Bethlehem, possibly even to the birth of the son from the Father before all time. The constant factor, however, is the position of the text-immanent reader. He is presented with a reenacting development which began in the 'today' of the text, which in turn is situated in the past while simultaneously bringing God's saving actions into the now.

\section{Initiation and Transformation}

Psalm 2 is a fascinating poem, but its main focus is not the initiation of the one appointed by the Lord, even though diachronic exegesis has often concentrated on the enthronement rituals of the Jerusalem king. This initiation belongs to the moment of 'today', but in the poem this moment is in the past. The result of the initiation is crucial for its impact on others. This is why this result is given a different semantic content in the II-elements and III-elements: 'anointed' and 'son'. Both designations occur on the basis of a direct speech by the Lord. The text-immanent author concurs with these designations. 
The transformation of the fettered kings is the poem's central focus. They are isolated and appear isolated, communicating without addressing anyone beside themselves. But ultimately they are addressed by someone, albeit neither by the Lord nor by the one appointed by him. In this ultimate address there is a hidden perspective that they may still ending up on the positive side. Whether this actually takes place or not is left undecided in the poem.

The text-immanent reader is a witness to this particular transformation and can therefore also apply it to himself, even without sharing the condition or attitude of the fettered kings. He is drawn into the poem as an outsider to experience the transformation.

In the two examples of the reception of Psalm 2 that were mentioned, initiation is applied to various events from Jesus' life: both his resurrection in Jerusalem and his birth in Bethlehem. But it is not simply the initiation that forms the central focus. Because the link to the moment of 'today' has been retained in these instances of reception, the focus remains on the effects of these initiations on the text-immanent reader, whether through the 'we' of the letter from the New Testament, or the singing congregation that is addressed in midnight mass. These rereadings therefore continue the transformation process developed in Psalm 2.

\section{Bibliography}

Bovati P (1994) Re-Establishing Justice: Legal Terms, Concepts and Procedures in the Hebrew Bible (Journal for the Study of the Old Testament Supplement Series 105). Sheffield: Sheffield Academic Press.

Brooke GJ (2004) The Psalms in Early Jewish Literature in the Light of the Dead Sea Scrolls. In Moyise S and Menken MJJ (eds) The Psalms in the New Testament. London: T\&T Clark, pp. 5-24.

Brown WP (2010) Psalms (Interpreting Biblical Texts). Nashville, TN: Abingdon.

Clines DJA, ed (1995) The Dictionary of Classical Hebrew, volume 2. Sheffield: Sheffield Academic Press.

Curtis AHW (2007) 'Our Father...': an Inherited Title and Its Presence (or Absence) in the Psalms? In Becking B and Peels E (eds) Psalms and Prayers: Papers Read at the Joint Meeting of the Society of Old Testament Study and Het Oudtestamentisch Werkgezelschap in Nederland en België, Apeldoorn, August 2006 (Oudtestamentische Studiën 55). Leiden: Brill, pp. 45-63.

Fokkelman JP (2000) Major Poems of the Hebrew Bible at the Interface of Prosody and Structural Analysis, volume 2 (Studia Semitica Neerlandica 41). Assen: Van Gorcum.

van Grol H (2015) Een inleiding in de klassiek Hebreeuwse versbouw: Verkenningen in het grensgebied van versbouw en tekstanalyse (Theologische Perspectieven 11). Bergambacht: $2 \mathrm{VM}$. 
Granerød G (2010) A Forgotten Reference to Divine Procreation? Psalm 2:6 in Light of Egyptian Royal Ideology. Vetus Testamentum 60(3): 323-336.

Gruber MI (2004) Rashi's Commentary on Psalms (The Brill Reference Library of Judaism 18). Leiden: Brill.

Hunter AG (2005) Psalms (Old Testament Readings). London: Routledge.

Jacob B (1934) Das erste Buch der Tora: Genesis. Berlin: Schocken Verlag [reprint New York, NY: Ktav Publishing House].

Lam J (2014) Psalm 2 and the Disinheritance of Earthly Rulers: New Light from the Ugaritic Legal Text RS 94.2168. Vetus Testamentum 64(1): 34-46.

Kraus H (1992) Theology of the Psalms. Minneapolis, MN: Fortress.

Laude P (2005) Singing the Way: Insights in Poetry and Spiritual Transformation (Perennial philosophy series). Bloomington, IN: World Wisdom.

van der Lugt P (2006) Cantos and Strophes in Biblical Poetry with Special Reference to the First Book of the Psalter (Oudtestamentische Studiën 53). Leiden: Brill.

Otto E (2004) The Judean Legitimation of Royal Rulers in Its Ancient Near Eastern Contexts. In Human DJ and Vos CJA (eds) Psalms and Liturgy (Journal for the Study of the Old Testament Supplement Series 410). London: T\&T Clark, pp. 131-139.

Otto E (2010) Hermeneutics of Biblical Theology, History of Religion, and Theological Substance of Two Testaments: The Reception of Psalms in Hebrew. In Human DJ and Steyn GJ (eds) Psalms and Hebrews: Studies in Reception (Library of Hebrew Bible / Old Testament Studies 527). London: T\&T Clark, pp. 3-26.

Wallace HN (2007) King and Community: Joining with David in Prayer. In Becking B and Peels E (eds) Psalms and Prayers: Papers Read at the Joint Meeting of the Society of Old Testament Study and Het Oudtestamentisch Werkgezelschap in Nederland en België, Apeldoorn, August 2006 (Oudtestamentische Studiën 55). Leiden: Brill, pp. 267-277.

Weber B (2007) Psalm 1 als Tor zur Tora JHWHs: Wie Ps 1 (und Ps 2) den Psalter an den Pentateuch anschliesst. Scandinavian Journal of the Old Testament 21(2): 179-200.

van Wieringen A (2012) Communicatiegeoriënteerde exegese en tekstuele identiteit: geillustreerd aan het boek Amos. In van Wieringen A (ed) Theologie \& Methode (Theologische Perspectieven Supplement series 4). Bergambacht: 2VM, pp. 3-46.

van Wieringen A, Rikhof H (2012) De Zeven Sacramenten: Een Bijbeltheologische en Systematisch-theologische studie (Theologische Perspectieven Supplement Series 6). Bergambacht: 2vM. 